\title{
Assessment of Chicken Production, Marketing and Socio-Economic Situations in Some Selected Districts of Gambella Region, Ethiopia
}

\author{
Getachew Bekele $^{1 *} \quad$ Tsigabu Gabresillasse ${ }^{1} \quad$ Alemayehu Guteta $^{2} \quad$ Etalem Tesfaye $^{2}$ \\ 1.Department of Animal Production and Technology, College of Agriculture and Natural Resource, \\ Gambella University, P O Box 126, Gambella, Ethiopia \\ 2.National poultry program, Bishoftu Research Center, Ethiopian Agricultural research Institute, Bishoftu, \\ Ethiopia
}

\begin{abstract}
The present study was conducted in Gambella region of south west Ethiopia to assess the chicken production, marketing and socio-economic characteristics in some selected districts of the region. The study was conducted in selected districts that were based on accessibility criteria's and potentially to represent the region. The study involved under field conditions by using semi structured questionnaires for focus group discussions and key informant interviews. From four districts atotal of 384 farmers those have indigenous chickens ( 96 from each districts) were considered. Mean age of the respondents in the districts were $39.72 \pm 0.14$ at Lare, $43.29 \pm 0.12$ at Abobo, $42.18 \pm 0.15$ at Gambella Ketema Zuria and $43.31 \pm 0.13$ at Itang special districts. The family size per interviewed households (HHs), respectively was $6.21 \pm 0.17,5.43 \pm 0.16,5.11 \pm 0.15$ and $5.65 \pm 0.12$. Almost all the respondents indicated that broodiness characteristics were common in their flock in which 79(82.29\%) in Itang especial district, 77(80.21\%) in Abobo, 75(78.13\%) in Lare and 88(91.67\%) in Gambella Ketema zuria districts. The mode of transportation of chickens to the market were mainly by hand usually embracing $(69.01 \%)$ and hanging the chicken downward (30.99\%). According to the interviewed farmers, a comparative higher price of

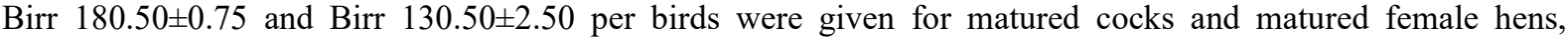
respectively during holidays and Birr $150.25 \pm 0.50$ and Birr $120.55 \pm 0.73$ per birds were given for matured cocks and matured female hens at regular time, respectively. Disease and shortage of feed were the first two major constraints in village chicken production, ranked first, and second, respectively in the study area. Generally, there are factors, including chicken management practices on housing, feed and feeding and market channel need improvement, which makes differences in chickens' production and marketing situation in the study area, which suggests that there is an opportunity to improve poultry production and marketing in the future.
\end{abstract}

Keywords: Marketing, Poultry production, Selected districts, Socio economics.

DOI: $10.7176 / \mathrm{JMCR} / 70-04$

Publication date:August $31^{\text {st }} 2020$

\section{Introduction}

World's chicken population estimated to be about 16.2 billion of which $71.6 \%$ were found in developing countries reported by Bushra (2012). Such poultry species contributed important socio-economic roles for food securities, generating additional cash incomes and religious/cultural functions (Tadelle, 2003). Due to this reason many of the world's rural poor are dependent on chicken production (Solomon, 2007). Chickens are one of the poultry species (chicken, ducks, guinea fowl) farming widely and practiced in Africa almost at every farmstead, some keeps poultry mainly for consumption and cash sales others for religious and cultural considerations by resource poor farmers in Africa (Dwinger et al., 2003). About 60\% of East African characterized chicken population is found in Ethiopia which plays a significant role in human nutrition as well as a source of cash income (Mekonnen, 2007).

Ethiopia, with its wide variations in agro-climatic conditions, possesses one of the largest and the most diverse plant and animal genetic resources in the world (Azage et al., 2010). Ethiopia is the home of domestic animal migration from Asia to Africa which plaid a great impact to widespread distribution in a country (Halima, 2007). Indigenous chickens in Ethiopia found in huge number (97.3\%) that distributed across different agro-ecological zones (CSA, 2011). Furthermore, their widespread distribution indicates their adaptive potential to the local environmental conditions, diseases and other stresses (Halima, 2007). Adaptation of harsh environment and resistance to disease are the major opportunities of local chicken in Ethiopia and contributed to the national economy in general and the rural economy in particular. The $68.46 \%$ of annual meat productions are produced by poultry and the egg productions are contributed by Indigenous chicken, hybrid and exotic breed with an average annual output of $85,918,543,16,137,806$ and $34,707,761$ of egg production, respectively (CSA, 2017/18). Additionally, the productivity of indigenous chicken is low as compared to exotic breeds with average annual egg production of 60 eggs/hens (Fisseha et al., 2010a). On the other hand, the live weight of indigenous chicken is about $1.6 \mathrm{~kg}$ and $1.3 \mathrm{~kg}$ for male and female, respectively at 6 months of age (Mekonnen, 2007). This initiated the 
government to modernize poultry production by introducing exotic breeds since 1990s (Abebe, 2008). Indigenous chickens in Ethiopia are found in huge numbers distributed across different agro ecological zones under a traditional family-based scavenging management system (Alemu and Tadelle, 1997). The total poultry population at country level is estimated to be about 56.06 million regarding breed, $88.19 \%, 6.45 \%$ and $5.36 \%$ of the total poultry were reported to be indigenous chicken, hybrid chicken and exotic breed, respectively (CSA, 2018). Indigenous breeds show a large variation in body size, color, comb type and productivity (Tadelle, 2003; Halima, 2007; Fisseha et al., 2010b).

A substantial amount of phenotypic diversity for various traits in the indigenous chicken genetic resources of Ethiopia is expected because of diverse agro-climates, ethnic groups, and socioeconomic, religious and cultural considerations. The majorities $(99 \%)$ of these chickens are maintained under a traditional system with little or no inputs for housing, feeding or health care (Tadelle and Ogle, 2001). This indicates that virtually every family in rural Ethiopia practices traditional chicken production because they provide protein for the rural population and generate family income. The most dominant chicken types reared in this system are local ecotypes, which show a large variation in body position, plumage color, comb type and productivity (Teketel 1986; Tadelle 2003; Halima 2007). In general, indigenous chickens are non-descriptive, with a variety of morphological appearances (Halima, 2007). Breed improvement and subsequent proper utilization of these local chicken genotypes strongly demands comprehensive assessment, including production systems, marketing and husbandry practice. With this, the objective of the study was aimed to assess poultry production, marketing and socio-economic situations in some selected districts of Gambella region, Ethiopia.

\section{Materials and Methods \\ Description of the Study Area}

The study was conducted in selected districts of Gambella region which is in the South West part of Ethiopia between the geographical coordinates of $6^{0} 28^{\prime} 38^{\prime \prime}$ to $8^{0} 34^{\prime}$ North Latitude and $33^{0}$ to $35^{0} 11^{\prime} 11^{\prime \prime}$ East Longitude and covers an area about $34,063 \mathrm{~km}^{2}$. The Region is bounded to the North, North East and East by Oromia region, to the South and South East by the Southern Nations and Nationalities People's Regional State (SNNPRS) and to the Southwest, West and Northwest by the Republic of South Sudan. The mean annual temperature of the Region varies from $17.3^{\circ} \mathrm{C}$ to $28.3^{\circ} \mathrm{C}$ and annual monthly temperature varies throughout the year from $27^{\circ} \mathrm{C}$ to $35^{\circ} \mathrm{C}$. The maximum temperature occurs in mid-March and is about $45^{\circ} \mathrm{C}$. The annual rainfall of the Region in the lower altitudes varies from $900-1500 \mathrm{~mm}$. At higher altitudes, it ranges from 1,900-2,100mm. Livestock population of the region is 285,102 Cattle, 35,285 Sheep, 107,083 Goats, 904 Horse ,100 Mules, 2,150 Donkey, 301,531 Poultry, 98,422 Beekeeping (CSA, 2017/18).

\section{Sampling Method and Data Collection}

A rapid reconnaissance survey was made before the main survey to know the distribution and concentration of local chicken eco-types and villages. Therefore, from the 13 districts of the region, four districts were selected purposively: namely, Itang especial Woreda, Lare, Abobo and Gambella Ketema Zuria. The study districts were selected based on their potential in chicken population and road accessibility. A total of 96 households were randomly selected from each of the four districts and a total of 384 households (HHs) addressed.

\section{Methods of Data collection}

Primary and secondary data were collected through individual interviews with the help of semi structured questionnaires. In addition, formal discussions were held with a group of HHs in each of the villages of indigenous chicken producers to get the overall primary data from informants.

\section{Statistical Analysis}

All data were coded and recorded in Microsoft excel sheet. Statistical analyses were made separately for male and female chicken on variables that varied on sex; otherwise the data were merged and analyzed together. Descriptive statistics such as mean, frequency and percentage were calculated, and all the surveyed data were analyzed. The descriptive statistics (mean+SE) for numerical survey data was subjected to analysis of variance (ANOVA) using the General Linear Model (GLM) procedure of SAS version 9.1, 2008. Mean comparisons were made by using Tukey`s studentized range test method at $\mathrm{p}<0.05$. The statistical model used was:

Where,

$$
Y_{i j=} \mu+A_{i}+C_{i j}
$$

$$
\begin{aligned}
Y_{i j}= & \text { the value of the respective variable mentioned above pertaining to the } i^{\text {th }} \text { Woreda (i=4, Itang } \\
& \text { especial, Lare, Abobo or Gambella Ketema Zuria) } \\
\mu= & \text { overall mean of the respective variable }
\end{aligned}
$$




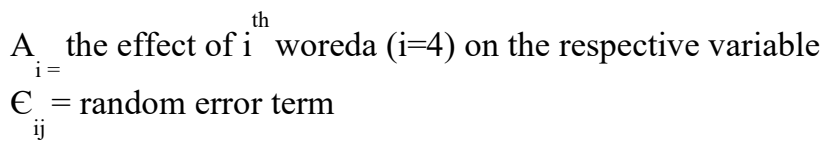

\section{Results and Discussions}

\section{Socio-economic status and respondent's profile}

General characteristics of the respondents studied were presented in Table 1. From the total interviewed village chicken owners in the study area were, more than half, $(70.87 \%)$ male and $(29.13 \%)$ were females. The average age of the respondents was 43.31 years in Itang especial, 39.72 years in Lare, 43.29 years in Abobo and 42.18 years in Gambella Ketema Zuria. Concerning educational background, the majority (47.14 \%) of the respondents were illiterate. This considerably high number of illiterates might influence negatively the perception of village chicken technology transfer. The number of illiterates observed in this study was higher than the reported $6.9 \%$ for Dale, Wonsho and Loka Abaya Woreda's of SNNPRS (Mekonin, 2007) and the reported 26.67\% for Northbench, Sheko and South-bench Woreda's of Bench Maji Zone (Getachew et al., 2015). However, the present result is lower than $72.34 \%$ for Jarso Woreda's of Oromia (Eskinder, 2013). The overall mean family size of the study area was 5.6 which is higher than the national average of 4.6 persons (CSA, 2011) and lower than the findings of Fisseha et al., (2010b) who reported 6.2 and 6.9 persons per household for Bure and Dale woreda and lower than the findings of Getachew et al. (2015) who reported 5.80 persons per household for north bench Woreda's. However, this is comparable to 5.4 persons per household for Northwest Amhara (Halima, 2007).

Table 1. Socio-economic characteristics of the respondents in village chicken production system

\begin{tabular}{|c|c|c|c|c|c|}
\hline \multirow[t]{2}{*}{ Parameters } & \multicolumn{4}{|l|}{ Districts } & \multirow{2}{*}{$\begin{array}{l}\text { Overall } \\
\text { mean }\end{array}$} \\
\hline & $\begin{array}{l}\text { Itang } \\
\text { special }\end{array}$ & Lare & Abobo & $\begin{array}{l}\text { Gambella Ketema } \\
\text { zuria }\end{array}$ & \\
\hline Age of the respondents & $43.31 \pm 0.13$ & $39.72 \pm 0.14$ & $43.29 \pm 0.12$ & $42.18 \pm 0.15$ & $42.13 \pm 0.14$ \\
\hline Family size/HH & $\begin{array}{cc}5.65 & \pm \\
0.12^{\mathrm{ab}} & \end{array}$ & $\begin{array}{rr}6.21 & \pm \\
0.17^{\mathrm{b}} & \end{array}$ & $\begin{array}{rr}5.43 & \pm \\
0.16^{\mathrm{a}} & \end{array}$ & $5.11 \pm 0.15^{\mathrm{ab}}$ & $5.6 \pm 0.15$ \\
\hline Sex & \multicolumn{4}{|c|}{ (Frequency, (\%) } & \\
\hline Male & 67.23 & 72.45 & 69.27 & 74.53 & 70.87 \\
\hline Female & 32.77 & 27.55 & 30.73 & 25.47 & 29.13 \\
\hline \multicolumn{5}{|l|}{ Educational background } & \\
\hline Illiterate & $43(44.79)$ & $45(46.88)$ & $46(47.92)$ & $47(48.96)$ & $181(47.14)$ \\
\hline Read \& write & $27(28.13)$ & $24(25.00)$ & $27(28.13)$ & $21(21.88)$ & $99(25.78)$ \\
\hline Primary education & $17(17.71)$ & $16(16.67)$ & $13(13.54)$ & $15(15.63)$ & $61(15.89)$ \\
\hline $\begin{array}{l}\text { Secondary education and } \\
\text { above }\end{array}$ & $9(9.38)$ & $11(11.46)$ & $10(10.42)$ & $13(13.54)$ & $43(11.19)$ \\
\hline Livestock holding/HH & \multicolumn{4}{|l|}{ Mean \pm SE } & \\
\hline Cattle & $4.12 \pm 0.31^{b}$ & $12.11 \pm 0.13^{\mathrm{a}}$ & $4.35 \pm 0.25^{\mathrm{b}}$ & $4.12 \pm 0.31^{b}$ & $6.17 \pm 0.25$ \\
\hline Sheep & $3.42 \pm 0.42^{\mathrm{c}}$ & $4.63 \pm 0.52^{\mathrm{a}}$ & $3.93 \pm 0.39^{\mathrm{b}}$ & $4.48 \pm 0.49$ & $4.12 \pm 0.46$ \\
\hline Chicken & $5.71 \pm 0.29^{b}$ & $6.47 \pm 0.09^{\mathrm{ab}}$ & $7.23 \pm 0.06^{\mathrm{a}}$ & $6.81 \pm 0.05$ & $6.56 \pm 0.12$ \\
\hline Goat & $6.31 \pm 0.16^{\mathrm{b}}$ & $5.83 \pm 0.25^{\mathrm{c}}$ & $6.57 \pm 0.34^{\mathrm{a}}$ & $6.47 \pm 0.31$ & $6.29 \pm 0.27$ \\
\hline
\end{tabular}

a, b, cmeans with different superscript letters across a row are significantly different at $\mathrm{p}<0.05$; HH=interviewed households.

\section{Purpose of keeping indigenous chickens}

Village chicken's production in the context of smallholder farmers was multi-directional purpose (Table 2). The results of rankings from the study area in the present study had shown that chickens serve as source of egg production ranked first, by which generate income was ranked second. The study also, indicated that the produced egg used for income generation ranked first and for hatching purposes ranked second. This is like Fisseha et al. (2010a) and Getachew et al. (2015) which agrees with the present study. Similarly, Halima (2007) reported that income generation was the primary objectives of chicken rearing in Southern and Northwestern Amhara. 
Table 2. Purpose of village chicken rearing and eggs production

\begin{tabular}{|c|c|c|c|c|c|c|}
\hline \multirow[t]{2}{*}{ Districts } & \multicolumn{3}{|c|}{\begin{tabular}{|r|} 
Purpose of chickens \\
\end{tabular}} & \multicolumn{3}{|c|}{ Purpose of egg } \\
\hline & Income & Meat & Egg production & Income & Consumption & Hatching \\
\hline \multicolumn{7}{|c|}{ Itang especial } \\
\hline Rank 1 & 32 & 25 & 39 & 51 & 17 & 28 \\
\hline Rank 2 & 36 & 13 & 47 & 56 & 18 & 22 \\
\hline Rank 3 & 37 & 16 & 43 & 52 & 24 & 20 \\
\hline Index & 0.36 & 0.20 & 0.44 & 0.55 & 0.22 & 0.26 \\
\hline \multicolumn{7}{|l|}{ Lare } \\
\hline Rank 1 & 37 & 24 & 35 & 46 & 23 & 27 \\
\hline Rank 2 & 40 & 22 & 34 & 47 & 25 & 24 \\
\hline Rank 3 & 39 & 20 & 37 & 48 & 19 & 29 \\
\hline Index & 0.34 & 0.24 & 0.36 & 0.49 & 0.24 & 0.31 \\
\hline \multicolumn{7}{|l|}{ Abobo } \\
\hline Rank 1 & 38 & 13 & 45 & 46 & 21 & 29 \\
\hline Rank 2 & 29 & 19 & 48 & 42 & 23 & 31 \\
\hline Rank 3 & 31 & 21 & 44 & 47 & 25 & 24 \\
\hline Index & 0.35 & 0.17 & 0.48 & 0.47 & 0.23 & 0.30 \\
\hline \multicolumn{7}{|c|}{ Gambella Ketema Zuria } \\
\hline Rank 1 & 30 & 23 & 43 & 46 & 20 & 30 \\
\hline Rank 2 & 31 & 18 & 47 & 52 & 24 & 20 \\
\hline Rank 3 & 34 & 21 & 41 & 37 & 27 & 32 \\
\hline Index & 0.32 & 0.22 & 0.39 & 0.48 & 0.24 & 0.28 \\
\hline
\end{tabular}

Index $=$ sum of [ 3 for rank $1+2$ for rank $2+1$ for rank 3] for particular trait divide by sum of [ 3 for rank $1+2$ for rank $2+1$ for rank 3] for all traits.

\section{Responsible Members of Chicken Production Activities}

The result from Table 3 indicated that women and daughter in the study area covered most of the responsibility of chicken production activities such as natural incubation of eggs, feeding, caring for baby chicks and sick chicken and cleaning the house. Similarly, Tadelle and Ogle (2001) indicated that in Ethiopia, management of chicken is fully in the domain of women, while decision on control and access to resources varies considerably.

Table 3. Members responsible for chicken production activities

\begin{tabular}{|c|c|c|c|c|c|c|c|}
\hline \multirow{2}{*}{$\begin{array}{l}\text { Family } \\
\text { Members }\end{array}$} & \multicolumn{7}{|c|}{ Activities in frequency, $(\%)$} \\
\hline & Purchasing & Selling & caring & Feeding & $\begin{array}{l}\text { Harvesting of } \\
\text { egg }\end{array}$ & Incubation & Cleaning \\
\hline $\begin{array}{l}\text { Young } \\
\text { Male }\end{array}$ & $64(16.67)$ & $\begin{array}{l}81 \\
(21.09)\end{array}$ & $39(10.16)$ & $30(7.81)$ & $49(12.76)$ & --- & --- \\
\hline $\begin{array}{l}\text { Young } \\
\text { Female }\end{array}$ & 69 (17.97) & $\begin{array}{l}111 \\
(28.91)\end{array}$ & $\begin{array}{l}113 \\
(29.43)\end{array}$ & $\begin{array}{l}120 \\
(31.25)\end{array}$ & $106(27.60)$ & $67(17.45)$ & $\begin{array}{l}177 \\
(46.09)\end{array}$ \\
\hline $\begin{array}{l}\text { Adults } \\
\text { Male }\end{array}$ & $117(30.47)$ & $37(9.64)$ & $45(11.72)$ & $\begin{array}{l}43 \\
(11.19)\end{array}$ & $39(10.16)$ & $116(30.21)$ & $29(7.55)$ \\
\hline $\begin{array}{l}\text { Adult } \\
\text { Female }\end{array}$ & $134(34.89)$ & $\begin{array}{l}155 \\
(40.36)\end{array}$ & $187(48.69)$ & $\begin{array}{l}191 \\
(49.74)\end{array}$ & $190(49.48)$ & $201(52.34)$ & $\begin{array}{l}178 \\
(46.35)\end{array}$ \\
\hline
\end{tabular}

As shown in Table 3, the chicken population in most of the studied area is based mainly on scavenging system and women and children traditionally play an important management role.

\section{Husbandry Practice}

Lack of separate chicken housing is one of the constraints of the village chicken production systems. In the current study $86.46 \%$ of the respondents replied to lack a separate chicken house (Table 4). This result is similar with the case reported by Mekonin (2007), Meseret (2010), Eskindir (2013) and Getachew at el. (2015) who reported 97.6\% in Dale, Wonsho and Loka Abaya Woreda's of SNNPRS, 94.4\% in Gomma Woreda, 92.06\% in both Horro and Jarso and $93.33 \%$ in bench Maji zone, respectively. The remaining $13.54 \%$ of respondent constructed a separate house for their chicken. This result is less than the finding of Halima (2007) and Bogale (2008) who reported that majority of the rural households kept chicken in prepared separate house as $22.1 \%$ of northwest Ethiopia and $59.7 \%$ of Fogera Woreda, respectively. 
Table 4. Housing and reasons (\%) for not having a separate shelter for their chickens

\begin{tabular}{|c|c|c|c|c|c|}
\hline \multirow[t]{2}{*}{ Housing conditions } & \multicolumn{4}{|c|}{ Districts } & \multirow{2}{*}{$\begin{array}{l}\text { Overall } \\
\text { mean }\end{array}$} \\
\hline & Itang especial & Abobo & Lare & $\begin{array}{c}\text { Gambella } \\
\text { Ketema } \\
\text { Zuria }\end{array}$ & \\
\hline Perches in the veranda & $53(55.21)$ & $59(61.46)$ & $55(57.29)$ & $51(53.13)$ & $55(57.29)$ \\
\hline Perches in the main house & $19(19.79)$ & $17(17.71)$ & $21(21.88)$ & $18(18.75)$ & $19(19.79)$ \\
\hline Separate shelter & $11(11.46)$ & $12(12.5)$ & $14(14.58)$ & $13(13.54)$ & $13(13.54)$ \\
\hline Perches in the kitchen & $13(13.54)$ & $8(8.33)$ & $6(6.25)$ & $14(14.58)$ & $10(10.42)$ \\
\hline \multicolumn{6}{|c|}{ Reason not having separate shelter (\%) } \\
\hline $\begin{array}{lrl}\text { Lack of knowledge } \\
\text { (awareness) }\end{array}$ & $25(26.04)$ & $28(29.17)$ & $24(25)$ & $26(27.08)$ & $26(26.08)$ \\
\hline $\begin{array}{l}\text { Less attention given to } \\
\text { chicken }\end{array}$ & $12(12.5)$ & $15(15.63)$ & $16(16.67)$ & $17(17.71)$ & $15(15.63)$ \\
\hline $\begin{array}{l}\text { Lack of construction } \\
\text { material }\end{array}$ & $24(25)$ & $22(22.92)$ & $25(26.04)$ & $22(22.92)$ & $24(25)$ \\
\hline Risk of predators & $17(17.71)$ & $13(13.54)$ & $12(12.5)$ & $15(15.63)$ & $12(12.5)$ \\
\hline Risk of theft & $13(13.54)$ & $12(12.5)$ & $8(8.33)$ & $13(13.54)$ & $12(12.5)$ \\
\hline Small flock size & $5(5.21)$ & $6(6.25)$ & $11(11.46)$ & $3(3.13)$ & $6(6.25)$ \\
\hline
\end{tabular}

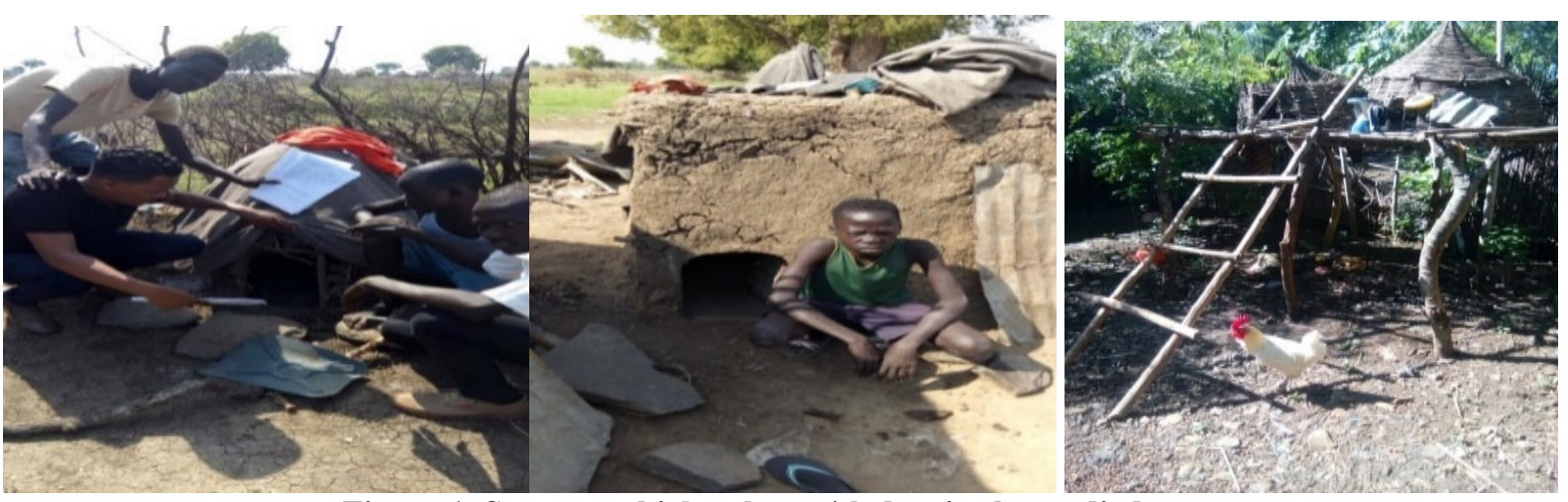

Figure 1. Separate chicken house/shelter in the studied area.

\section{Feeding}

According to the results of this study, all the respondents (100\%) replied to practice scavenging system with supplementary feeding. This is also similar with the findings of Zemene et al. (2012) who reported $100 \%$ chicken owners in west Amhara region and Getachew et al. (2015) who reported 100\% chicken owners in bench Maji zone practiced scavenging system with additional supplementary feed. Cereal grains (maize, sorghum, wheat and household scraps) are the major supplementary feeds provided, and the amount given being dependent on seasons of the year of harvesting and the quantity and availability of the resources at the HH level.

Table 5. Type and provision of supplementary (Percent) feeding for chickens

\begin{tabular}{|l|c|c|c|c|}
\hline $\begin{array}{l}\text { Provision of Supplementary } \\
\text { feeding (Percent) }\end{array}$ & \multicolumn{4}{|c|}{ Districts } \\
\cline { 2 - 5 } & Itang especial & Abobo & Lare & $\begin{array}{c}\text { Gambella Ketema } \\
\text { Zuria }\end{array}$ \\
\hline Yes & $96(100)$ & $96(100)$ & $96(100)$ & $96(100)$ \\
\hline No & - & - & - & - \\
\hline Type of supplementary feeds & \multicolumn{5}{|l|}{} \\
\hline Maize & $96(100)$ & $96(100)$ & $96(100)$ & $96(100)$ \\
\hline Wheat & $29(30.21)$ & $33(34.38)$ & $25(26.04)$ & $37(38.54)$ \\
\hline Sorghum & $87(90.63)$ & $91(94.79)$ & $89(92.71)$ & $93(96.88)$ \\
\hline Household scraps & $41(42.71)$ & $53(55.21)$ & $55(57.29)$ & $49(51.04)$ \\
\hline
\end{tabular}

$\mathbf{a}=$ Percentages do not add up to $100 \%$ since respondent's selected more than one feed type 


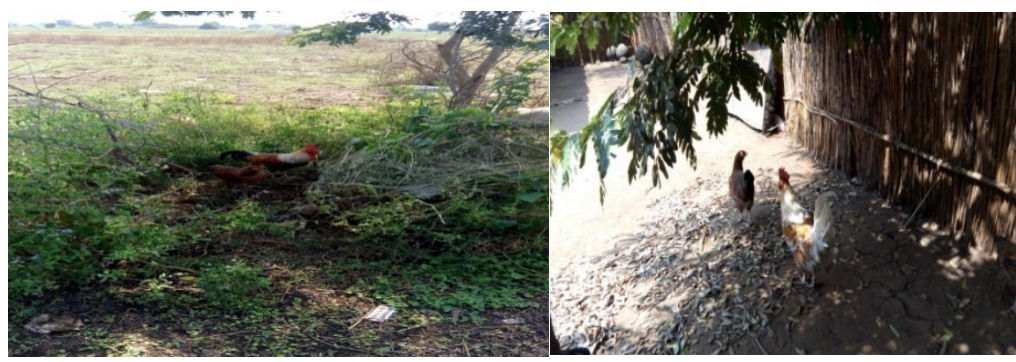

Figure 2. During scavenging in the studied area

\section{Watering}

The present study also indicated that all chicken owners were used flat plastic container, broken clay locally called "shekila", plastic made trough and metal made trough as watering in all districts of the studied area.

Table 6. Practice, frequency of watering and type of water trough for chickens

\begin{tabular}{|c|c|c|c|c|c|}
\hline \multirow[t]{2}{*}{ Factors } & \multicolumn{4}{|c|}{ Districts } & \multirow{2}{*}{$\begin{array}{l}\text { Overall } \\
\text { mean }\end{array}$} \\
\hline & $\begin{array}{l}\text { Itang } \\
\text { especial }\end{array}$ & Abobo & Lare & $\begin{array}{c}\text { Gambella Ketema } \\
\text { Zuria } \\
\end{array}$ & \\
\hline \multicolumn{6}{|c|}{ Provision of water to Chicken (\%) } \\
\hline Yes & $96(100)$ & $96(100)$ & $96(100)$ & $96(100)$ & $96(100)$ \\
\hline No & - & - & - & - & - \\
\hline \multicolumn{6}{|l|}{ Frequency of watering } \\
\hline Once a day & - & - & - & - & - \\
\hline Twice a day & $23(23.96)$ & $15(15.63)$ & $9(9.38)$ & $14(14.58)$ & $10(10.42)$ \\
\hline Three times a day & $3(3.12)$ & $2(2.08)$ & - & $5(5.21)$ & $3(3.12)$ \\
\hline $\begin{array}{l}\text { Ad libtum (offered } \\
\text { freely) }\end{array}$ & $70(72.92)$ & $79(82.29)$ & $87(90.63)$ & $77(80.21)$ & $78(81.25)$ \\
\hline \multicolumn{6}{|l|}{ Type of water Trough } \\
\hline Brocken clay material & $11(11.46)$ & $17(17.71)$ & $12(12.5)$ & $15(15.63)$ & $14(14.58)$ \\
\hline Plastic made & $68(70.83)$ & $69(71.88)$ & $72(75)$ & $63(65.63)$ & $68(70.83)$ \\
\hline Metal made trough & $17(17.71)$ & $10(10.42)$ & $12(12.5)$ & $18(18.75)$ & $12(12.5)$ \\
\hline
\end{tabular}

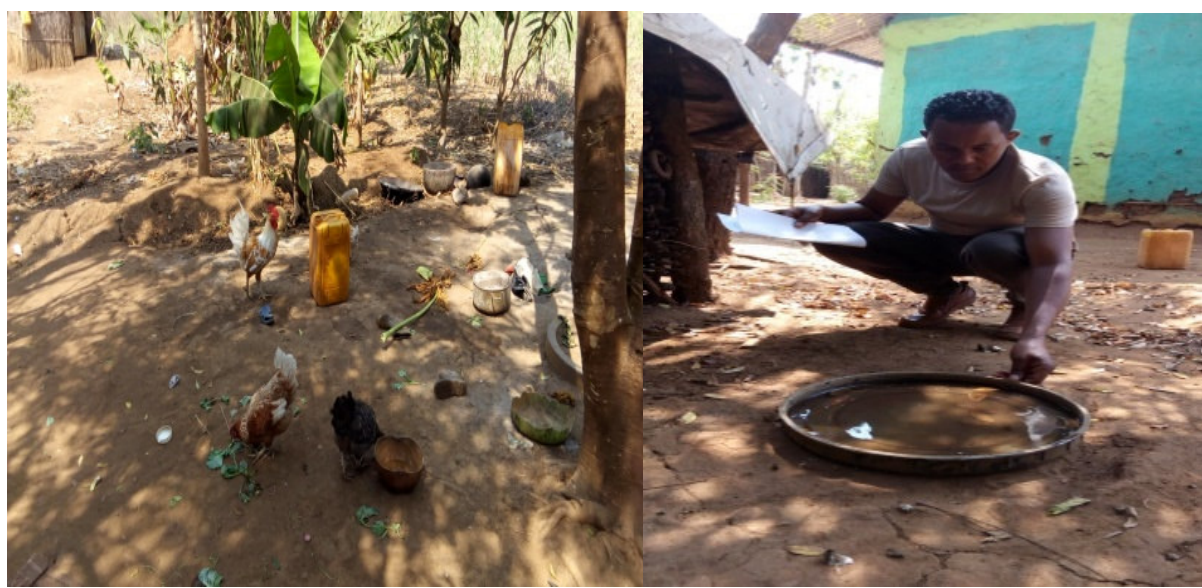

Figure 3. Plastic and metal made water trough in the study area

\section{Marketing system of chicken and products}

Marketing systems of village chicken and eggs in Ethiopia is one of the functions of keeping free-range chickens by smallholder farmers. The major characteristics of chicken markets are shown in Table 7. In general, there is no systematic marketing operation of chicken and chicken products in the study areas. Selling of live birds and eggs were a common practice in the region as well as in the study sites. The fixed market days that holds every week at Abobo and Itang especial Woredas are on Saturday, market every week at Gambella Ketema Zuria district on Wednesday, whereas a market day at Lare district are on Monday, Tuesday and Friday. More than half of the respondents $(77 \%)$ do not have any information about the price of a chicken before they went to markets. Only $33 \%$ get price information who either obtains information from their neighbors $73(57.48 \%)$ or after they reach to the market $54(42.51 \%)$. 
Table 7. Marketing characteristics of the studied area

\begin{tabular}{|c|c|c|c|c|c|}
\hline \multirow[t]{2}{*}{ Characteristics } & \multicolumn{4}{|c|}{ Districts } & \multirow[t]{2}{*}{ Overall mean } \\
\hline & $\begin{array}{l}\text { Itang } \\
\text { especial }\end{array}$ & Abobo & Lare & $\begin{array}{c}\text { Gambella } \\
\text { Ketema Zuria }\end{array}$ & \\
\hline \multicolumn{2}{|l|}{ Price information (127) } & \multicolumn{2}{|c|}{35} & 22 & 38 \\
\hline From neighbors (\%) & $17(53.13)$ & $19(54.23)$ & $13(59.09)$ & $24(63.18)$ & $73(57.48)$ \\
\hline From the market $(\%)$ & $15(46.87)$ & $16(45.77)$ & $9(40.91)$ & $14(36.82)$ & $54(42.51)$ \\
\hline \multicolumn{6}{|c|}{ Death of chickens during Transport } \\
\hline Yes $(\%)$ & ------ & $\begin{array}{ll}---- \\
-1\end{array}$ & $\begin{array}{ll}---- \\
--1\end{array}$ & $\begin{array}{ll}---- \\
\end{array}$ & $\begin{array}{ll}----- \\
\end{array}$ \\
\hline No $(\%)$ & 100 & 100 & 100 & 100 & 100 \\
\hline \multicolumn{6}{|l|}{ Mode of transport (384) } \\
\hline Embracing by hand (n) & 73 & 65 & 68 & 59 & $265(69.01 \%)$ \\
\hline Hanging by hand (n) & 23 & 31 & 28 & 37 & $119(30.99 \%)$ \\
\hline Carrying by basket (n) & - & - & - & - & - \\
\hline \multicolumn{6}{|l|}{ Season of selling (384) } \\
\hline Rainy Season(n) & 43 & 37 & 36 & 43 & 43 \\
\hline Dry Season(n) & 33 & 42 & 29 & 31 & 33 \\
\hline Any Season(n) & 20 & 17 & 31 & 22 & 20 \\
\hline
\end{tabular}

On the average, farmers in the surveyed area traveled $2.49 \mathrm{~km}$ ranged from $0.5-6 \mathrm{~km}$ to reach to the market's places. The mode of transportation of chickens by farmers (producer) were mainly by hand usually embracing $(69.01 \%)$ and hanging the chicken downward (30.99\%).

\section{Channel of marketing of live birds and eggs}

The marketing channel followed is simple usually chickens and eggs are often sold by farmer's reaches to consumers directly and in most of the cases after being passed through intermediates called village level collectors and market level collectors (Middlemen). The most common form of chicken marketing channels with the volume of sale in the study area is shown in Table 8 . About $60.67 \%$ of the poultry passed through intermediaries (collectors in the open market), $3.75 \%$ reach through village collectors/ Neighbors, and $36.03 \%$ directly to the consumer. Comparing the four Woredas (Table 12) in Lare and Gambella Ketema Zuria Woredas the largest number of chickens $60(62.5 \%)$ and $55(57.29 \%)$ passed through the market level collectors (intermediaries) in the open market, respectively.

Table 8. Marketing channels in the four Woredas

\begin{tabular}{|l|l|l|l|}
\hline \multirow{2}{*}{ Districts } & \multicolumn{3}{|c|}{ Sell to stakeholders (\%) } \\
\cline { 2 - 4 } & $\begin{array}{l}\text { Village collectors/ } \\
\text { Neighbors }\end{array}$ & $\begin{array}{l}\text { Collectors in the } \\
\text { market }\end{array}$ & Sell to consumers \\
\hline Itang especial & $3(3.125)$ & $51(53.125)$ & $42(43.75)$ \\
\hline Lare & $2(2.08)$ & $60(62.5)$ & $34(35.42)$ \\
\hline Abobo & $4(4.16)$ & $53(55.21)$ & $39(40.63)$ \\
\hline Gambella Ketema Zuria & $7(7.29)$ & $55(57.29)$ & $34(35.42)$ \\
\hline Overall mean & $16(4.17)$ & $219(57.03)$ & $149(38.80)$ \\
\hline
\end{tabular}

\section{Price of chickens and products at farm gate}

The respondents' estimation of chicken price during ordinary and holidays is presented in Table 9. Variations in poultry prices are not only influenced by weight and age of chickens but also by seasons and holidays. Farmers get better prices for both egg and live birds during holiday markets. According to farmers, comparatively higher prices Birr $180.50 \pm 0.75$ and Birr $130.50 \pm 2.50$ per birds were given for matured cock and matured female hen, respectively during holidays. There was a premium price during Christmas and Ethiopian Easter. The prices offered in these findings were relatively very higher compared to Tadelle (2003) who reported Birr 21.5 with a range of 12.5-30 and Birr 13.4 with a range of 9-10 for matured cock and matured female, respectively during holidays. This finding is still higher than that of Assefa (2007) who reported Birr 27.24 and 15.51 for matured male and female birds, respectively in the study made in and around Umbullo Wachu watershed of Awassa Zuria. For unit egg, farmers get comparatively better price of $4.50 \pm 0.50$ Birr again on a holiday market. This price is very higher when compare to Birr 0.46 per egg reported by Tadelle (2003) for Debre Zeit area in the year 2001 during festival of Ethiopian Easter (0.40-0.50 Birr) and reported by Assefa (2007) in the study made in and around Umbullo Wachu watershed. The current result was higher than that of Kibreab Yosefe et al. (2016) who reported the average price of adult cock, hen and young chicken were reached 75 birr, 54 birr and 38 Birr, respectively and the price of egg was reached 2 Birr during non-fasting period and 2.25 at festival time. 
Table 9. Farm gate chicken price

\begin{tabular}{|l|l|l|l|l|}
\hline \multirow{2}{*}{ Chicken category } & \multicolumn{5}{|c|}{ In Regular Days (Birr, Mean \pm SD) } \\
\cline { 2 - 5 } & Itang & Lare & Abobo & Gambella Ketema Zuria \\
\hline Matured male & $120.14 \pm 0.14$ & $100.11 \pm 0.12$ & $125.34 \pm 0.50$ & $150.25 \pm 0.50$ \\
\hline Matured female & $90.75 \pm 0.13$ & $82.85 \pm 0.13$ & $110.85 \pm 0.23$ & $120.55 \pm 0.73$ \\
\hline Grower male & $81.34 \pm 0.50$ & $73.04 \pm 1.30$ & $93.33 \pm 2.50$ & $110.65 \pm 2.50$ \\
\hline Grower female & $65.72 \pm 0.42$ & $61.08 \pm 1.22$ & $83.02 \pm 1.82$ & $100.25 \pm 1.50$ \\
\hline Unit Egg & $3.0 \pm 0.25$ & $3.00 \pm 0.10$ & $3.50 \pm 0.25$ & $4.00 \pm 0.50$ \\
\hline \multicolumn{5}{|c|}{ In Holidays (Mean \pm SD) } \\
\hline Matured male & $130.14 \pm 0.16$ & $120.50 \pm 0.25$ & $135.25 \pm 0.60$ & $180.50 \pm 0.75$ \\
\hline Matured female & $110.75 \pm 0.33$ & $110.50 \pm 0.60$ & $120.45 \pm 0.50$ & $130.50 \pm 2.50$ \\
\hline Grower male & $90.34 \pm 0.60$ & $90.05 \pm 1.50$ & $105.60 \pm 1.50$ & $120.60 \pm 1.50$ \\
\hline Grower female & $85.52 \pm 0.22$ & $79.25 \pm 1.50$ & $90.50 \pm 2.25$ & $110.50 \pm 2.25$ \\
\hline Unit Egg & $4.0 \pm 0.01$ & $3.80 \pm 0.10$ & $4.00 \pm 0.50$ & $4.50 \pm 0.50$ \\
\hline
\end{tabular}

\section{Conclusion and Recommendations}

This study involved field visits, focus group discussions and key informant interviews. The most dominant chicken production systems in the study area were the back yard extensive systems based on the local indigenous birds and scavenging with occasional and seasonal supplementary feeding of homegrown grains and household food refusals with no specific chicken houses. Most of the respondents do not have any information about the price of chicken before they went to markets. As it is the case for most rural areas in Ethiopia, there were also no well-organized formal chicken and chicken's products marketing channel. The reported critical constraints of the smallholder poultry production in the study area were partly due to the prevailing poor management practices, predation, lack of proper health care, poor housing and poor marketing information. The current study indicated that the chicken production is widely practiced in the entire study Districts. Hence, it is important that the research and development initiatives in the future should emphasize on the improvement of indigenous chickens through the adoption of improved feed, health care, marketing channels and improved management systems. Therefore, training should focus on improved predators and diseases control measures, construction of chicken houses from locally available materials and some feeding management options to enhance farmers' chicken production and productivity. Farmers should also be aware and give special attention on major constraints of the chicken production to improve the productivity and production of indigenous chicken.

\section{Reference}

Abebe Wossene. 2008. Review of the new features of the Ethiopian poultry sector: Biosecurity implications. Food and Agriculture Organization of the United Nations.24pp.

Alemu Yami and Tadelle Dessie. 1997.The Status of Poultry Research and Development in Ethiopia, Research Bulletin No. 4. Poultry Commodity Research Program Debre Zeit Agricultural Research Center, Alemaya University of Agriculture, Ethiopia.

Assefa Tadesse. 2007 Poultry management practices and on Farm Performance Evaluation of Rhode Island Red (RIR), Fayoumi and Local chicken in Umbullo Wachu Watershed. MSc. Thesis, Hawassa College of Agriculture, Hawassa, Ethiopia.

Azage Tegegne, Berhanu Gebremedhin and Hoekstra D. 2010. Livestock input supply and service provision in Ethiopia: Challenges and opportunities for market oriented development.

Bogale Kibret. 2008. In situ characterization of local chicken eco-type for functional traits and production system in Fogera District, Amhara regional state; M.Sc. Thesis Submitted to the Department of Animal Science School of Graduate Studies, Haramaya University.107pBulletin No. 331, Addis Ababa, Ethiopia.35pp.

Bushra B. 2012. The status of indigenous village chicken production and marketing system in Ethiopia. MSc. Thesis, Addis Ababa University.

CSA (Central Statistical Authority). 2017/18. Agricultural sample survey vol. II.

CSA (Central Statistical Authority). 2011. Agricultural sample survey volume .2: statistical bulletin 505. Report on livestock and livestock characteristics (prevent peasant holdings), Addis Ababa, February 2011.21.

Dwinger R.H, Bell J.G and Permin A. 2003 A program to improve family poultry production in Africa.B.P.6268, Rabat-Institutes, Morocco.

Eskindir Aklilu, Kefelegn Kebede and Tadelle Dessie. 2013. Phenotypic characterization of chicken in Ethiopia. International Journal of Interdisciplinary and Multidisciplinary Studies, 1: 24-32. Ethiopia.

Fisseha Moges, Aberra Melesse, and Tadelle Dessie. 2010a. Assessment of village chicken production system and evaluation of the productive and reproductive performance of local chicken ecotypes in Bure district, North West Ethiopia. African Journal of Agricultural Research Vol. 5(13): 1739-1748, 4 July, 2010. 
Fisseha Moges, Azage Tegegne, and Tadelle Dessie. 2010b. Indigenous chicken production and marketing systems in Ethiopia: Characteristics and opportunities for market-oriented development. Working paper No.24; Improving Productivity and Market Success (IPMS) of Ethiopian Farmers Project, International Livestock Research Institute (ILRI). Addis Ababa, Ethiopia.66pp.

Getachew Bekele, Kefelegn Kebede and Negassi Ameha. 2015. On-farm Phenotypic Characterization of Indigenous Chicken and their Production System in Bench Maji Zone, South Western Ethiopia. Science, Technology and Arts Research Journal, 2015, 4(1): 68-73.

Halima Hassen. 2007. Phonotypic and genetic characterization of indigenous chicken populations in Northwest Ethiopia. PhD. Thesis submitted to the faculty of National and agricultural sciences department of animal Wildlife and Grass land Sciences University of the Free State, Bloemfontein, South Africa.176-186pp.

Kibreab Yosefe, Zelalem Abate, Kassa Tarekegn, Dakamo Fisseha and Dessiye Tesfaye. 2016. Poultry Production, Management and Marketing System at Selected Districts of Kafa and Bench Maji Zone, South West Ethiopia. Journal of Biology, Agriculture and Healthcare, Vol.6 (11): 2224-3208, 2016.

Mekonnen G/egziabher. 2007. Characterization of smallholder poultry production and marketing system of dale, Wonsho and Loka Abaya Woreda's of southern Ethiopia. M.Sc Thesis, Awassa College of Agriculture, Hawassa University.95pp.

Meseret, Molla. (2010) Characterization of Village Chicken Production and Marketing System in Gomma Woreda, Jimma Zone, Ethiopia, Msc Thesis, Jimma University, Ethiopia.

SAS (Statistical Analysis System) (2008). SAS Institute Inc., Cary, NC, USA.V.9.2

Solomon Demeke. 2007. Suitability of hay-box brooding technology to rural household poultry production system. Livestock research for rural development 19 (1) 2007.Jimma University College of Agriculture and Veterinary Medicine, Jimma, Ethiopia.1pp.

Tadelle Dessie and Ogle B. 2001. Village poultry production systems in the central highlands of Ethiopia. Tropical Animal Health and Production, 33: 521-537.

Tadelle Dessie. 1996. Studies on village poultry production systems in the central highlands of Ethiopia. MSc. Thesis, Swedish University of Agricultural Sciences.

Tadelle Dessie. 2003. Phenotypic and genetic characterization of local chicken ecotypes in Ethiopia. PhD Thesis, J.L. University of Geissen, Germany, 209p.

Teketel Forsido. 1986. Studies on the meat production potential of some local strains of chicken in Ethiopia. $\mathrm{PhD}$ Thesis. J.L. University of Giessen, Germany. 210p.

Zemene Worku, Aberra Melesse, \& Yosef T/Giorgis. 2012.Assessment of Village chicken production system and the performance of local chicken population in West Amhara Region of Ethiopia. Journal of Animal Production Advances, 2 (4):199-207. 